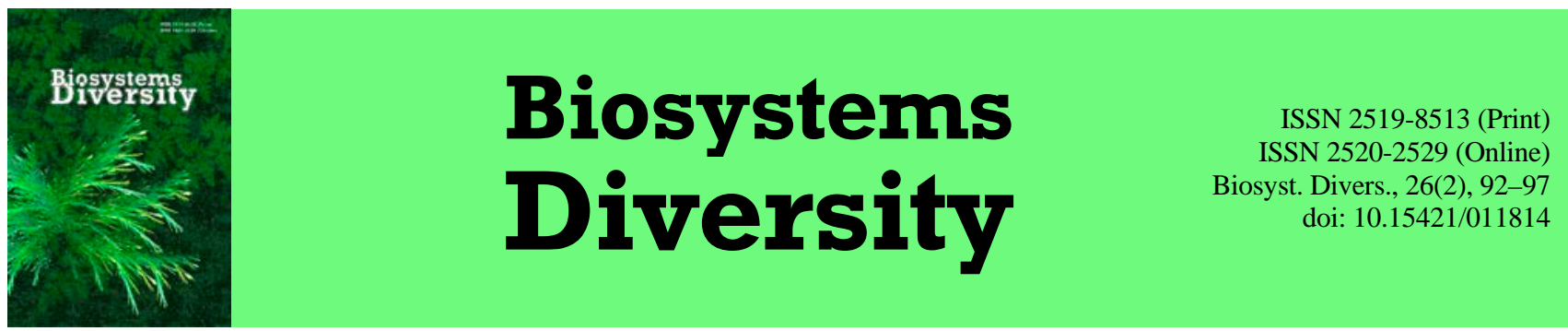

\title{
New species of Sorbus (Rosaceae) for the flora of the Nakhchivan Autonomous Republic (Azerbaijan)
}

\author{
A. M. Ibrahimov*, A. V. Matsyura** \\ *Institute of Bioresources of Nakhchivan Section of Azerbaijan National Academy of Sciences, Nakhchivan, Azerbaijan \\ **Altai State University, Barnaul, Russian Federation
}

Received 10.03.2018

Received in revised form 02.05.2018

Accepted 06.05.2018

Ibrahimov, A. M., \& Matsyura, A. V. (2018). New species of Sorbus (Rosaceae) for the flora of the Nakhchivan Autonomous Republic (Azerbaijan). Biosystems Diversity, 26(2), 92-97. doi:10.15421/011814

Institute of Bioresources of Nakhchivan Section of Azerbaijan National Academy of Sciences, Babek st., 10, Nakhchivan, AZ 7000, Azerbaijan.

E-mail: enver_ibrahimov@mail.ru

Altai State University, Lenin st., 61,

Barnaul, 656049, Russia.

Tel: +7-385-224-37-53.

E-mail: amatsyura@gmail.com

As a result of perennial researches conducted, as well as the analysis of the herbaria materials and literature sources during expeditions to the various areas of the Nakhchivan Autonomous Republic during 2004-2017, the following new species of rowans, Sorbus albovii Zinserl., S. armeniaca Hedl., S. buschiana Zinserl., S. caucasica Zinserl., S. fedorovii Zaikonn., S. kusnetzovii Zinserl., S. migarica Zinserl. and S. tamamschjanae Gabr., were identified for the flora of the Nakhchivan Autonomous Republic. The article includes information about the synonyms of the types, regularity of distribution depending on altitude zones, bloom and ripening duration.

Keywords: Nakhchivan Autonomous Republic; Sorbus; new species; systematics; new distribution areas; Red Book of the Republic of Azerbaijan

\section{Introduction}

The Nakhchivan Autonomous Republic is one of the richest regions of Azerbaijan for plant diversity. Among the wild fruits, species of rowans (Sorbus L.) have been selected according to systematic composition. During the course of research (Grossheim, 1952; Prilipko, 1954; Gasumova et al., 2014) some 11 species of the Sorbus L. type were identified, namely - S. aucuparia L., S. boissieri Schneid., S. baldascii Deg. et Fritsch. ex Schneid., S. graeca (Spach) Lood. ex Schauer, S. luristanica (Bornm.) Schönbeck-Temesy, S. persica Hedl., S. roopiana Bordz., S. subfusca (Ledeb.) Boiss., S. takhtajanii Gabr., S. turcica Zinserl., S. umbellata (Desf.) Fritsch in this area. However, as a result of analysis of the pomological features of the herbaria collected during the expeditions conducted during 2004-2017 in the various areas of Nakhchivan Autonomous Republic, literature review (Grossheim, 1952; Prilipko, 1954; Ibragimov, 2008; Talibov \& Ibragimov, 2013), and comparison of examples of the herbaria materials kept in the fund of the Institute of Botany of the Academy of Sciences of Azerbaijan, Institute of Bioresources of Nakchivan Branch of the Academy of Sciences of Azerbaijan and herbaria fund of the Nakhchivan State University we identified some new species for the flora of the Nakhchivan Autonomous Republic of the Azerbaijan Republic; S. albovii Zinserl., S. armeniaca Hedl., S. buschiana Zinserl., S. caucasica Zinserl., S. fedorovii Zaikonn., S. kusnetzovii Zinserl., S. migarica Zinserl. and S. tamamschjanae Gabr.

\section{Materials and methods}

In order to clarify the current situation of the representatives of Sorbus L. in the flora of the Azerbaijan Republic, we checked the herbariums kept at Herbarium Fund of the Botany Institute of Azerbaijan National Academy of Sciences, Bioresources İnstitute of the Nakhchivan Branch of Azerbaijan National Academy of Sciences, Nakhchivan State University. We also performed comparative analysis of herbarium samples from various institutions and organizations web sites. We also determined the status of Sorbus L. genus during the field expeditions of 2004-2017 (Ibragimov, 2008; Askerov, 2011, 2016; Talibov \& Ibrahimov, 2013). We used the data from (Zinzerling, 1939;
Grossheim, 1952; Konovalov, 1954; Prilipko, 1954; Gachechiladze, 1965; Trees..., 1970; Areas..., 1980) for identification of the species.

\section{Results}

1. S. albovii Zinserl. Zinserl. in the Flora USSR IX (1939) 390 and in Addenda, 8: 493. - S. aria var. concolor Albow, Prodr. fl. colch. (1895) 71. - S. aria var. concolor Boiss. Fl. Or. II (1872) 658 p. S. concolor C. K. Schn. Handb. D. Laubholzk. I (1906) 686 p.; Grossg., Flora of the Caucasus, IV (1934) 288.

It is either a tree or a shrub (Fig. 1a). Buds are naked or a little hairy. Leaves are obovate or ellipsis shape. A little shrunken in trunk or round shaped. Top side is sharp or obtuse, usually sharp tipped with 7-10 cm length and 4-7 cm width. Side veins number is 8-11 pairs, top side is naked (initially a little hairy along the veins), bottom side is green and little hairy. Sides are serrated, top side is hardly visible double serrated, sharp serrates reach the blade of the leaf. Sepal feels hairy, serrates are of triangular shaped and sharp. Petals are egg-shaped. Fruits are round or oval shaped of red color turning green afterwards. Blooms in MayJune and gives fruits in August-September.

Typus. Caucasus occidentalis, Reservatum Publicum Caucasicum, in declivibus septentrionalibus montis Abago in betuletis ad rivum, 3.VIII.1929, A. İ. Leskov et A. P. Rusaleev (LE).

Habitat. Distributed in the middle and high mountain ranges, spread among sparse forests and bushes at a height of 1,800-2,000 m (2200 m) above sea level.

Distribution. distributed in the sparse forest surrounding Nurgut village of the Ordubad district of the Nakhchivan Autonomous Republic, along with the oak, hawthorn, or pear types, or separately 18.VII. 2012. T. H. Talibov, A. M. Ibrahimov; In the oak forest in the area of Bichenek village of Shahbuz district 04.VII.2014. T. H. Talıbov, A. M. Ibrahimov. This typus was first time identified by Y. D. Zinzerling (1939) in 1929 as a result of herbaria samples collected. While Y. D. Zinzerling (1939) was systemizing the species related to Sorbus L. type he accepted S. albovii Zinserl. species as a separate species, however, E. C. Gabrielyan (1978) identified it as a synonym of S. subfusca (Ledeb.) Boiss. species. Despite I. T. Zaikonnikova (1980) also noting the similarity of 
S. albovii Zinserl. to S. subfusca (Ledeb.) Boiss., a species described on basis of samples collected in the North-West Caucasus (Abago Mountain), in her other article (Zaikonnikova, 1975) she accepted it as a separate species. According to I. T. Zaikonnikova (1980) the separation of S. albovii Zinserl. and S. subfusca (Ledeb.) Boiss. species is confirmed by the difference in their geographical distribution and the number of chromosomes. Although the species S. albovii Zinserl. is found almost all over the Caucasus, the territory of the species S. subfusca (Ledeb.) Boiss.

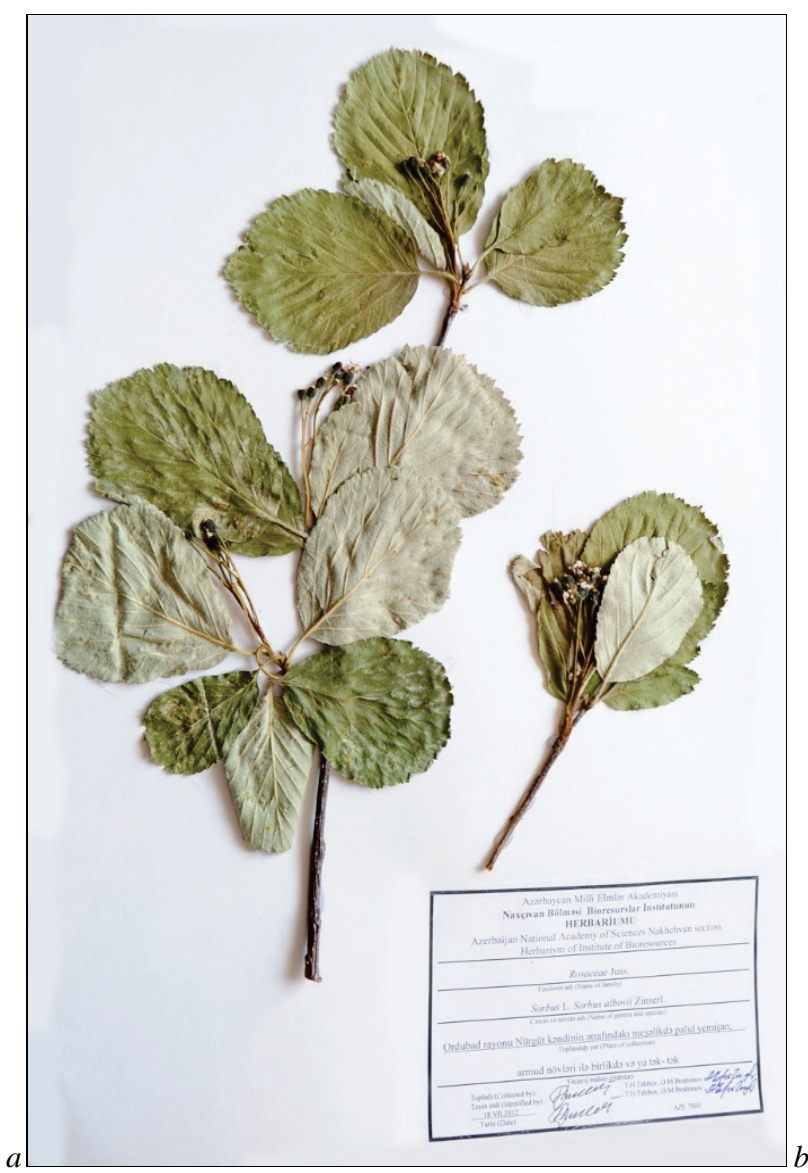

Fig. 1. Herbarium specimens of Sorbus albovii Zinserl (a) and S. armeniaca Hedl. (b)

2. S. armeniaca Hedl. Monogr. d. Gatt. Sorbus (1901) 69; S. K. Schneid., III. Handb. d. Laubholzk. I (1906) 693; Grossg., Flora of the Caucasus, IV (1934) 289; Zinserl. in the Flora USSR, IX (1939) 396; Grossg., The description of the plants of the Caucasus, (1949) 74; Grossg., Flora of the Caucasus, V (1952) 36; Prilipko, Flora of Azerbaijan, V (1954) 58; Trees and shrubs of Azerbaijan, III (1970) 45.

It is a shrub or stunted tree (Fig. 1b). The leaves are the egg shaped, ellipse or ellipsoid form. Deepens toward the trunk. Top is sharp and rarely blunt with a length of $6-8 \mathrm{~cm}$ and $3.5-5.0 \mathrm{~cm}$ width, edge with 5-7 margins that are not deep (lower margins reach to the half $1 / 2-1 / 3$ of the width of the leaf blade. It has 30-36 sharp teeth. From the top it is dark green and naked, beneath is grey or white with thick hairs. The number of side veins is 9-10 pairs, that are clearly visible from beneath the leaf. It is multiflorous. Sides of the sepal are sharply triangular in shape. Petals are white, egg shaped. Fruits are 1.0-1.2 cm length, 0.8-1.1 $\mathrm{cm}$ width and are oval or round shaped, squeezed from sides, gathered in scutellum alone or in 3-7 pieces. Mature fruits are red and turn blue when they dry. Blooms in May-June and gives fruits in September-October.

Lectotypus. Karabach orient in extreme margine sylvarum versus cucumen m. Kirs, 18.IX.1829, Szovits (LE, isolect. BM).

Habitat. It is spread between stone-rocky slopes, arid spruce forests and bushes at a height of 1,500 to 2,300 $\mathrm{m}$ above sea level in middle and high mountain ranges.

Distribution. In the sparse forest surrounding Nurgut village of the Ordubad district of the Nakhchivan Autonomous Republic, in conjuncttion with the types of oak, hawthorn, apple, pear, etc. or individually is limited to the western part of the Caucasus. Also, S. albovii Zinserl. type is tetraploid ( $2 n=68$ ), while $S$. subfusca (Ledeb.) Boiss. is diploid $(2 n=34)$. These species also differ according to the variety of morphological symptoms (form, size, edge of the leaf, etc.). For this reason, it is more expedient to treat S. albovii Zinserl. as a separate species as described by S. K. Czerepanov (1995). As noted by T. I. Zaikonnikova (1975), the species S. albovii Zinserl. is found only in Dagestan and the Nakhchivan Autonomous Republic.

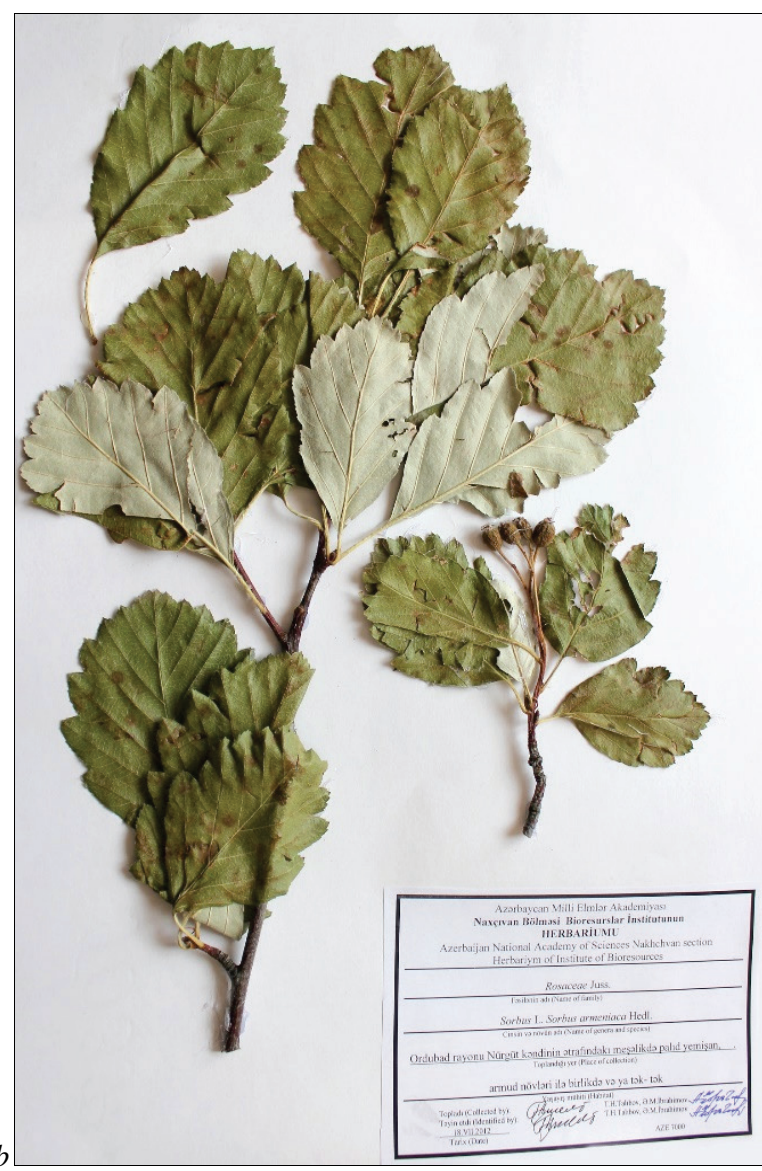

18.VII.2012. T. H. Talibov, A. M. Ibrahimov; Oak forest in Bichanak village of Shahbuz region 04.VII.2014. T. H. Talibov, A. M. Ibrahimov.

The species is derived from $S$. persica species in the form of the leaves, the depth of the slices (in the S. persica, this depth is $1 / 4$ to $1 / 5$ of the leaf), and $S$. caucasica type, the shape and smallness of the leaves, the form of the leaf base part and the top (the S. caucasica sections are two-thirds of a half width of the leaf moon) and uncut leaf boxes.

3. S. buschiana Zinserl. sp. n. in Addenda VIII, p.495; Grossg., The description of the plants of the Caucasus, (1949) 73; Grossg. Flora of the Caucasus, V (1952) 33.

It is a low tree or shrub of about 4-6 meters height (Fig. $2 a$ ). The leaves of $10-11 \mathrm{~cm}$ long are dual, while in the fruit growing shoots they are wide egg shaped-ellipsoid, and in the fruitless shoots they are of the lancet type. The number of side vessels is $10-11$ pairs, the edges are double edged. Bottom surface is grey greenish with felt hairs. Leaf base is a wedge shaped.

Typus. Delvars, inter pagas N. Ermani et Schavlochovo, in schistosis, alt. 1850-2200 m, E. et N. Busch (LE).

Habitat. It is spread in middle and high mountain ranges, steep rocky slopes at the altitudes of 1,800 to 2,200 $\mathrm{m}$ above sea level, in arid spruce forests and bushes.

Distribution. In the sparse forest surrounding Nurgut village of the Ordubad district of the Nakhchivan Autonomous Republic, along with oak, hawthorn, pear types, or even individually 16.VIII.2012. T. H. Talibov, A. M. Ibrahimov; Oak forest in Bichanak village of Shahbuz region 09.VIII.2013. T. H. Talibov, A. M. Ibrahimov. 
While Y. D. Zinzerling (1939) related S. buschiana Zinserl type as a separate species, E. C. Gabrelyan (1978) identified it as a synonym of S. subfusca (Ledeb.) Boiss. species.Although I. T. Zaikonnikova (1980) also noted the similarity of $S$. albovii Zinserl. to S. subfusca (Ledeb.) Boiss. species described on basis of samples collected in the NorthWest Caucasus (Abago Mountain), in another article (Zaikonnikova,

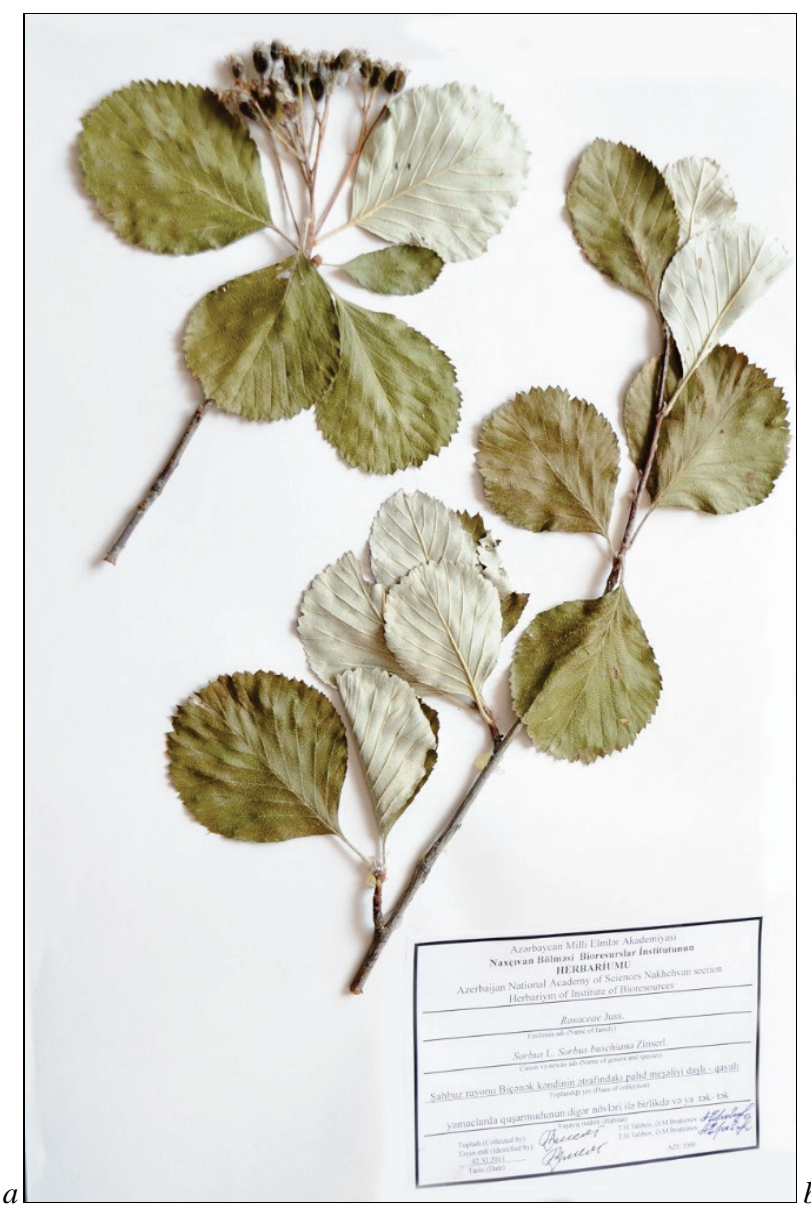

1975) she accepted it as a separate species. According to I. T. Zaikonnikova (1980) while S. buschiana Zinserl. is similar to S. albovii Zinserl due to the shape of its leaves and morphological features, it is still different in its thick skin type leaves greyish at the bottom, sepal with thick hairs and fruits. S. K. Czerepanov (1995) also accepted it as a separate species.

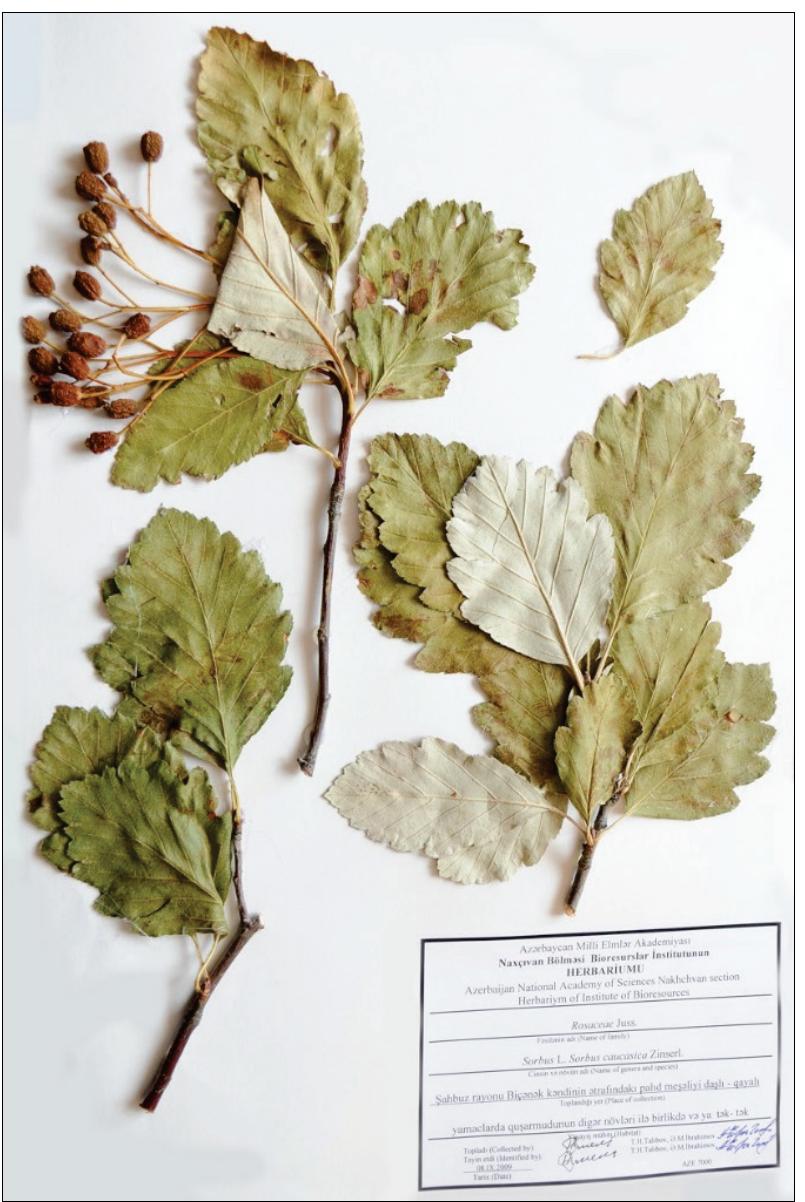

Fig. 2. Herbarium specimens of Sorbus buschiana Zinserl. (a) and S. caucasica Zinserl. (b)

4. S. caucasica Zinserl. in the Her. Inst. Bot. AS of USSR IV (1923) 17-18; Grossg. Flora of the Caucasus, IV (1934) 288; Zinserl. in the Flora USSR, IX (1939) 395; Kolakovsk, Flemish Abkh. II (1939) 297; Sosnovsk. in Flora of Georgia, V (1949) 352; Grossg., The description of the plants of the Caucasus, (1949) 74; Grossg. Flora of the Caucasus, V (1952) 34, - S. aria v. intermedia Akinph., Prilipko, Flora of Azerbaijan, V (1954) 58; Fl. Center. Kavk. 1 (1894) 159. S. aria v. incisa Al'bov in Proceedings Tiflis Bot. Gard. 1 (1895) 72. S. scandica auct. fl. cauc., non-fries. - S. woronowii; Shrubs and trees of Azerbaijan, III (1970) 45. A low tree is or shrub of about 4-6 meters in height (Fig. 2b). The leaves are obovate, round, wide ellipse or in some cases long ellipse, wedge shaped close to the leaf base. The tip is curly or pointy, (8) 10-12 (15) cm long and 6-11 cm wide. The outer margin is 5-7 lobes, which are not deeper (lobes reach up to 4 (1 to 3-1) of the width of the leaf). There are 30-35 pointed teeth, the apex is dark green, bare, and the bottom is dense gray or white with felt hairs.

The leaf blades are full-fledged from the inner side or there are only 1-2 smaller teeth in the upper part. The number of side veins is 79 pairs, the veins on the lower surface of the leaf are clearly visible and felt haired. The flower group is multiflorous, and the petiole is felt haired. The sepal is felt haired and the teeth are sharp and triangleshaped. The petals are white and obovate. The fruits are $1.0-1.4 \mathrm{~cm}$ in length, $0.6-1.1 \mathrm{~cm}$ in width, slightly oval, or slightly lengthened, gathered in 7-12 (20) pieces in the scutellum. The ripe fruit is red, it is bare, and it turns blue when it dries. Red-brown seeds are $0.5-0.6 \mathrm{~cm}$ length. The taste is not sweet, and it twists the mouth. Blossoms in May-June and fruits ripen in August-September.
Typus. Caucasus, Beshtau, 1,300 m above sea level, 23.V.1887, I. Akinfiev (holo, LE).

Habitat. It is spread in the middle and high mountain ranges, in the woods at the altitudes of 1,800-2,200 m above sea level, along the upper border of the forest, on rocky slopes, among the bushes on limestone soils.

Distribution. Oak woods in Bichanak village of Shahbuz region of the Nakhchivan Autonomous Republic 08.IX.2009. T. H. Talibov, A. M. Ibrahimov.

S. caucasica Zinserl. type S. armenica Hedl. and S. persica Hedl. are close to their species and easily hybridise with them. Considering that S. caucasica Zinserl. is a rare and endangered species, T. S. Mammadov, E. O. Iskandar and T. H. Talibov included it in their book of rare trees and shrubs (2016) and described methods of its protection.

5. S. fedorovii Zaikonn. Botanical. Magazine, 1974, 59, 11: 1605. -S. subfusca auct. non Boiss.

It is a shrub or tree with a height of $2 \mathrm{~m}$ (Fig. 3a). The leaves are 7$10 \mathrm{~cm}$ length, the edges are double, sometimes with deep teeth, and are turned egg or elliptic shaped. The tip is sharpened and is narrowed towards to the leaf base in a wedge shape. The veins on the lower side are clearly visible. Petiole is red-brown. The flowers are collected in a floral scutellum group. The sepal is felt haired, bubble and with obtuse teeth. Petioles are naked. The petals are white, ellipse width, almost twice the size of the sepal. Fruits are small, slightly curly, red and then becoming dark-blue. Blossoms in June, and fruits grow in September-October.

Typus. Ossetia Australis, Ermani, in latere sinistro angustiae fl. Bolschaja Liachva, prope pagum Schavlochovo, 13.VII.1938, defl., Fr. 
immat., L. I. Abramov (LE).

Habitat. It is spread in the middle and high mountain ranges, along the upper boundary of the forest at the altitudes 1,500-2,300 $\mathrm{m}$ above sea level, stony rocky slopes, arid spruce woods and shrubs.

Distribution. Around Hadi Kayiib, Guzuyatan areas of Akhura village of the Sharur region of the Nakhchivan Autonomous Republic and among forest bushes 23.VI.2009. T. H. Talibov, A. M. Ibrahimov. It is illustrated by T. I. Zaikonnikova (1974) on basis of herbarium

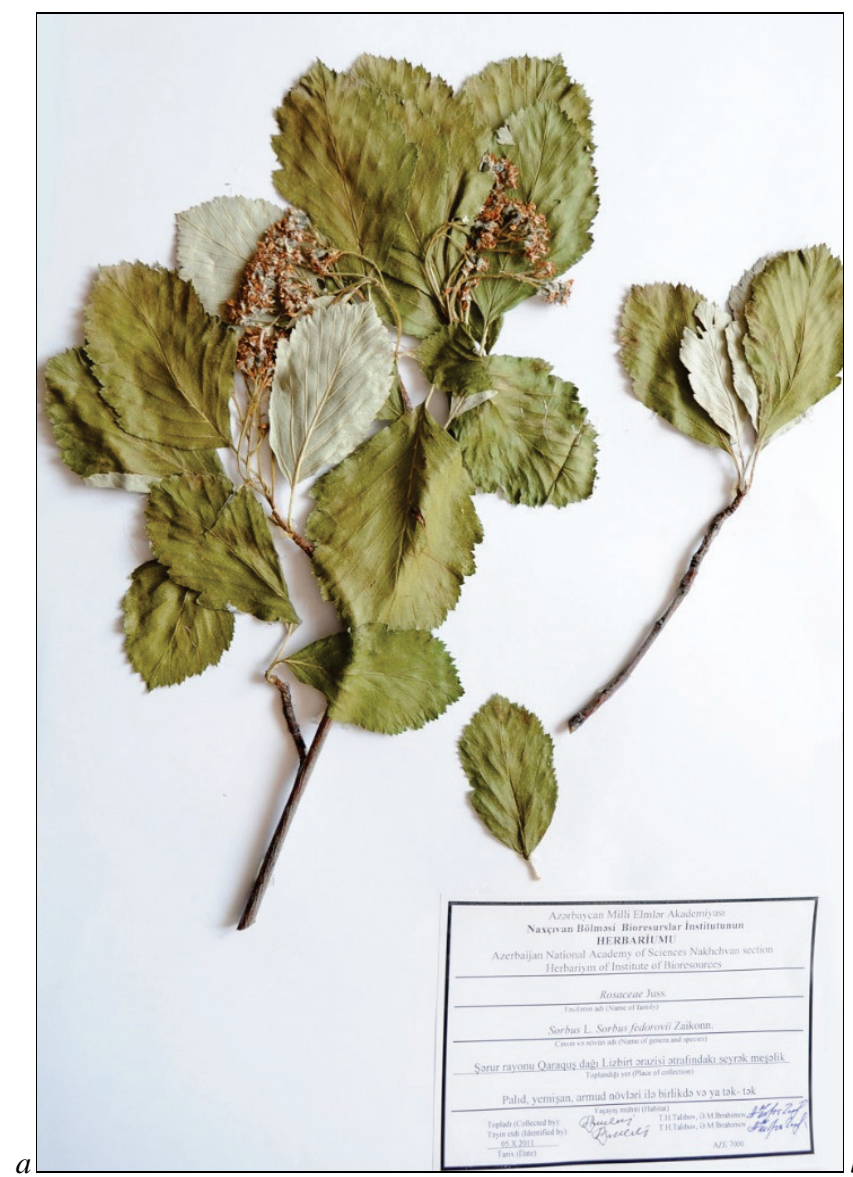

Fig. 3. Herbarium specimens of Sorbus fedorovii Zaikonn. (a) and S. kusnetzovii Zinserl. (b)

6. S. kusnetzovii Zinserl. Zinserl. in the Flora USSR, IX (1939) 397 et Add. VIII: 496; Grossg., The description of the plants of the Caucasus, (1949) 74; Grossg. Flora of the Caucasus, V (1952) 33, Prilipko, Flora of Azerbaijan, V (1954) 56; Gachechiladze, the Dendroflora of the Caucasus, IV (1965) 116; Zaikonnikova, Botan. Journal, 1980, 65, 9:1228; Zaikonnikova, Botan. Journal, 1982, 67, 1:101; Shrubs and trees of Azerbaijan, III (1970) 43.

It is a shrub with a height of $4-5 \mathrm{~m}$ (Fig. $3 b$ ). The buds are felt haired or rarely naked. The leaves are broad, turned epplictic, or elliptic, while the leaf base narrows to a wedge shape. The apex is sharp or rarely blunt, with length of $5-8 \mathrm{~cm}$ and width of $4.0-6.5 \mathrm{~cm}$. The upper side is bare, green, and the lower side is greyish with thick felt hair. The edge is double threaded, the number of side veins is $7-10$ pairs. The flower petiole is white felt haired, sepal is white felt haired, in a triangular shape with serrates. Petals are white, rounded. The fruit is almost curly, $1.3 \mathrm{~cm}$ length, $1.1 \mathrm{~cm}$ width and 11-16 gathered in scutellum. The mature fruit is red, bright and slightly hairy. Dark brown seeds are $0.6-0.7 \mathrm{~cm}$ long. Blossoms in May-June and fruits grow in September-October.

Typus. Caucasus ossidentalis, Reservatum Publicum Caucasicum in rupilus et pratulis in declivio australi montis Zakan, 12.VII.1930, A. İ. Leskov (LE).

Habitatl. It is spread in the middle and high mountain ranges, at the altitudes of 1,700-2,300 $\mathrm{m}$ above sea level in the oak woods, on the slopes of sparse forests, in open rocky slopes, and among shrubs. It is specimens collected from Ossetia. E. Gabrelian (1978) considers that $S$. fedorovii Zaikonn. type is a synonymous species of $S$. subfusca (Ledeb.) Boiss. According to T. I. Zaikonnikova not considering S. subfus$c a$ (Ledeb.) Boiss. as a polymorph and using the various signs on the shape changes illustrated $S$. fedorovii Zaikonn. species. However, as a result of analysis on the collected herbarium samples, it was clear that S. fedorovii Zaikonn. differs in its shape and size and the type of leaves, exuberance, edges density, fruits and so on.

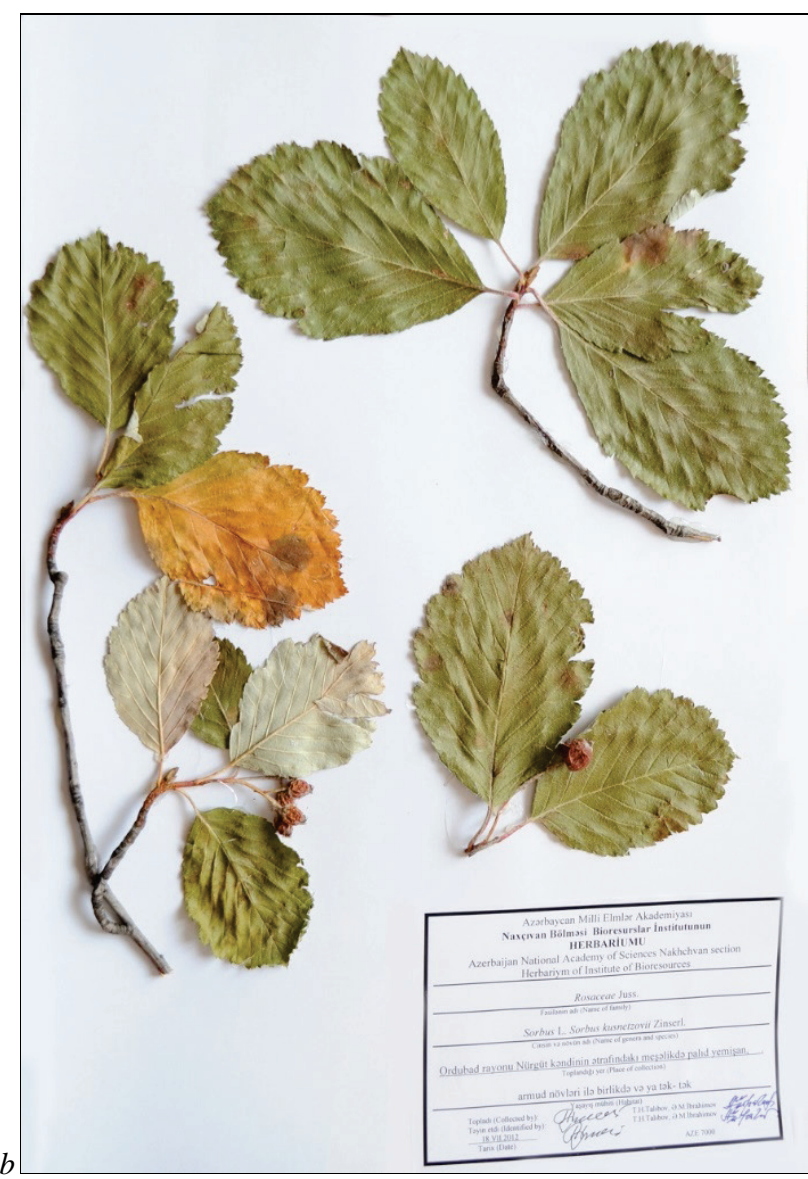

found alone or in groups in sparse oak woods or among shrubs along with Rhamnus cathartica L., Viburnum lantana L., Lonicera iberica Bieb., Sorbus graeca (Spach). ex Schauer, S. aucuparia L., Euonymus verrucosus Scop., Berberis iberica Stev. \& Fisch. ex DC., Juniperus oblonga Bieb. and so on.

Distribution. Oak forest in Bichanek village of Shahbuz district of the Nakhchivan Autonomous Republic 09.VIII.2013. T. H. Talibov, A. M. Ibrahimov; In the sparse forest surrounding Nurgut village of the Ordubad region, in combination with oak, hawthorn, apple, pear, hips, and so on or alone 04.IX.2015. T. H. Talibov, A. M. Ibrahimov.

This species is close to the species $S$. graeca, however differs in its clearly visible serrated leaf margins, characteristic hairy and red colored petals and fruits.

Despite A. M. Askerov stating in his book on Conspect of Azerbaijan Flora (Askerov, 2011) that S. kusnetzovii Zinserl. is spread in Azerbaijan, he subsequently denied this idea in his later book (Askerov, 2016). According to T. A. Gasimova, Z. S. Aliyeva and T. D. Safguliyeva (2014), the species S. kusnetzovii Zinserl.is spread in the middle and high mountain ranges of the Greater Caucasus at the altitudes of 1,200-2,400 $\mathrm{m}$ above sea level among oak woods, in sparse forests, on open rocky slopes, and in shrubs.

Considering that $S$. kuznetsovii Zinserl. is a rare and endangered species, T. S. Mammadov, E. O. Iskandar and T. H. Talibov included it in the book on rare trees and shrubs of Azerbaijan (2016) and described methods of its conservation. 

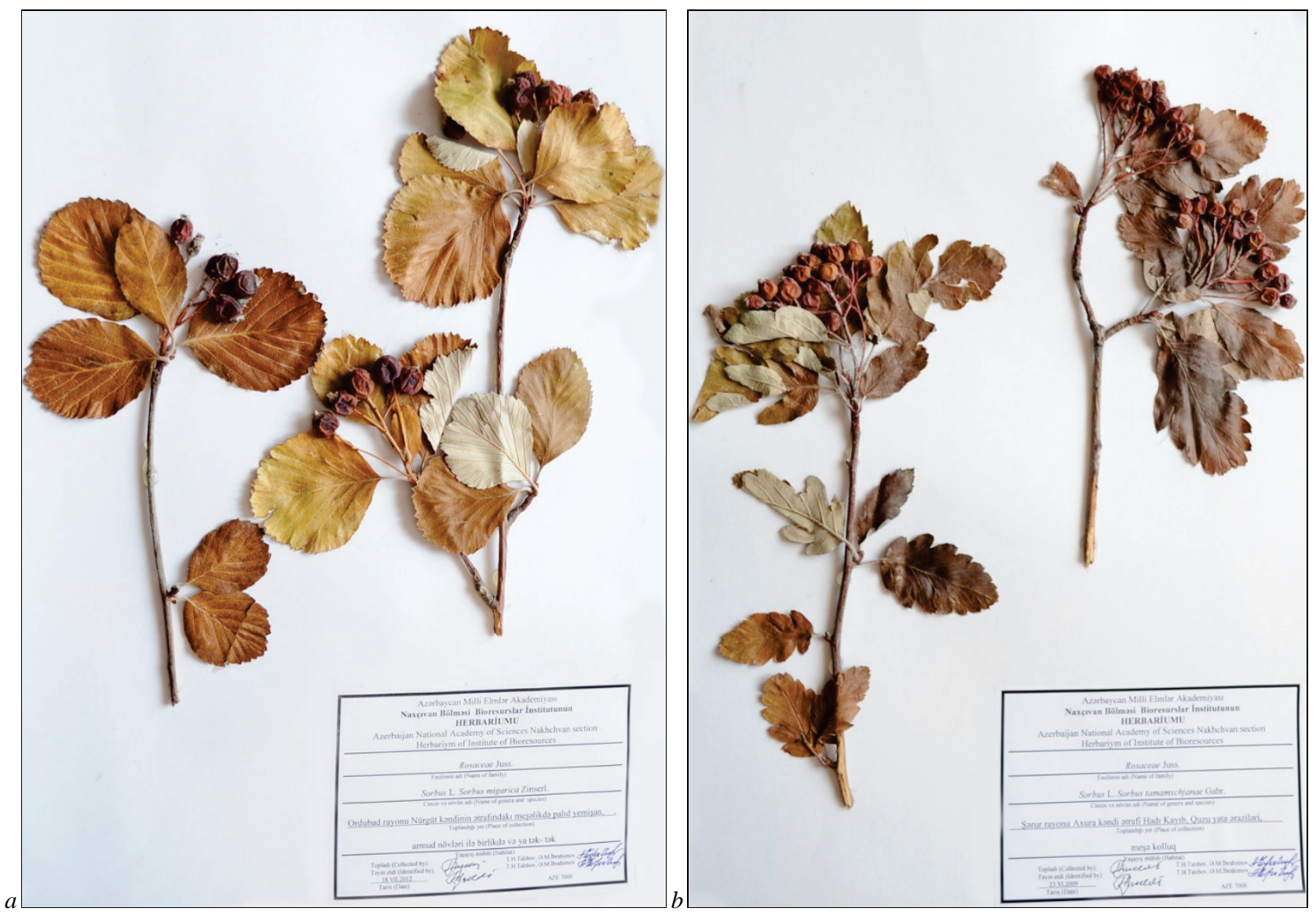

Fig. 4. Herbarium specimens of Sorbus migarica Zinserl. (a) and S. tamamschjanae Gabr. (b)

7. S. migarica Zinserl. Zinserl. in the Flora USSR, IX (1939) 398 et Add. VIII: 496, tabl. 26, 3 (fol.); Grossg., The description of the plants of the Caucasus, (1949) 74; Sosnovsk. in Flora of Georgia, V (1949) 353; Grossg. Flora of the Caucasus, V (1952) 34, tabl. 6, 2, sub $S$. graesa (excl. petiolum); Gachechiladze, the Dendroflora of the Caucasus, IV (1965) 115, fig. 19, 1 (fol.). - S. aria auct. non Crantz: Albov, Proceedings of the Tiflis Botanical Garden, 1 (1895) 70, r. r. (Prodr. Fl. Colch.). - S. graeca auct. non Hedl.: Zaikonnikova, Botan. Journal, 1973, 10:167.

It is a shrub of $0.5-2.0 \mathrm{~m}$ height (Fig. $4 a$ ). The buds are barely felt haired. Leaves are more or less dermal and round shaped, (5) 7-9(10) cm long, (4.5) 6-7 (8) cm width, apex is blunt. The number of side veins is 8-10 pairs. Upper surface except the veins are naked or barely hairy. Bottom surface veins are covered with thick white felt hair, surface of veins is barely haired. Therefore, veins are clearly visible by their dark color. The edges of the leaf are full margined from bottom, the tip is $(1 / 8-1 / 3)$ serrated. The serrates are small and sharp and their number is 20-25 from both sides. Leaf and flower stalk is short and white felt haired. Sepal is white felt haired, triangular shaped bending down after blossom and serrated. The mature fruit is dark red, with a length of 1.1$1.3 \mathrm{~cm}$ and a width of $1.0-1.2 \mathrm{~cm}$. Blossoms in May-June and fruits grow in September-October.

Typus. Megrelia, mons. Migaria, 21.VII.1936, P. Panjutin (LE).

Habitat. In middle and high mountain ranges, in the oak forests at altitudes of 1,800-2,000 $\mathrm{m}$ above sea level, along the upper border of the forest, in rocky slopes, in sparse arid forests and shrubs in the limestone lands.

Distribution. It is spread in sparse forest surroundings of Nurgut village in the Nakhchivan Autonomous Republic, either together with juniper, barberries, oak, hawthorn, pear, apple, hips etc. or or individually 02.XI.2011. T. H. Talibov, A. M. Ibrahimov.

It is closer to the species $S$. graeca and differs by its smaller petiole leaves. S. migarica Zinserl. the length of the petiole is $(0.2) 0.5-0.7(1.0) \mathrm{cm}$, while S.graeca is $1.0-1.5$ or $1.5-2.0 \mathrm{~cm}$ length. The serrates of the leaf margin are collected from the center of the apex of the leaf, not from the center of the leaf (or even not from the center to the base) as in S. graeca.
In the information of I. T. Zaikonnikova, S. migarica Zinserl species is registered as S. graeca var. cuneata Zinserl. on basis of subsequent analysis of herbarium samples collected from the Caucasus.

This kind of definition is also met in the samples stored in the Herbarium of the Institute of Botany of the Academy of Science of Azerbaijan (In the samples of the Herbarium Fund of the Institute of Botany of the Academy of Science of Azerbaijan, samples are shown as collected in Mazra and Urmus villages (16.08.1933, Karyagin) and Urmus village area (02.08.1933, İsayev; 15.08.1933, Karyagin) of the Ordubad region. Therefore, E. S. Gabrielyan (1978) showed S. migarica Zinserl species as a synonym of $S$. umbellata (Desf.) Fritsch var. orbiculata Gabr. (S. graeca var. orbiculata Zinserl.) species. However, as a result of analysis of the literature sources and of the collected herbarium smaples it was concluded that it is reasonable to accept $S$. migarica Zinserl. as a separate species due to the variety of its morphological characteristics and geographical area as was mentionned by S. K. Czerepanov (1995).

I. T. Zaikonnikova (1973) also mentioned that S. migarica Zinserl. species is not a narrowly endemic species as described by Y. D. Zinzerling (1939) but spread around the entire Caucasus.

8. S. tamamschjanae Gabr. Biol. Journal. Armenia, 1969, 22, 2:42. - S. dualis auct. p.p., non Zinserl. - S. armeniaca auct. p.p., non Hedl. - S. roopiana auct. p.p., non Bordz.

It is a shrub or a low tree of $2-5 \mathrm{~m}$ height (Fig. $4 b$ ). The leaves are egg shaped or elliptical, $2.5-9.0 \mathrm{~cm}$ length, $1.5-5.0 \mathrm{~cm}$ wide, close to the leaf base is narrowed in a wedge form, the apex is blunt. The top surface is dark green, bare, and the lower surface is dense gray or white felt haired. Its margin is slightly serrated and has a significant deep short lobe. The number of side veins is 7-9 pairs. Flower group is a multiflorous and peltate. The petiole initially is hairy and then becomes naked. The sepal serrates are triangular in shape,short and sharp. The petals are white and ovoid. The fruits are $1.2 \mathrm{~cm}$ in length, $1.1 \mathrm{~cm}$ in width and are wide-elliptic, 5-11 (18) are collected together in scutellum. The mature fruit is bright orange and bright. Light brown seeds are $0.6 \mathrm{~cm}$ in length, $0.2 \mathrm{~cm}$ in width. The taste is not sweet, and the mouth twists. Blossoms in May-June and fruits grow in September-October. 
Holotypus. Armenia, in vicinitate Khosrov, supra ruinas pagi Mangjuk, ad ripam sinistram fl. Qjusus, in silva, 1,800 m, 17.VI.1968, Gabrieljan (ERE, iso. LE, E).

Habitatl. In middle and high mountain ranges, in the oak forests at altitudes of 1,800-2,400 $\mathrm{m}$ above sea level, along the upper limit of the forest, on rocky slopes, in sparse arid forests and shrubs in the limestone lands.

Distribution. In the sparse forest around the Garagush mountain Lizbirt area of the Sharur region of the Nakhchivan Autonomous Republic, together with oak, hawthorn, pear, hips, nuts, etc. species or individually. 05.X 2011. T. H. Talibov, A. M. Ibrahimov; Sparse forest around Ayrinc village of Shahbuz region, 09.VII.2013; In the sparse forest surrounding Nurgut village of the Ordubad region, together with oak, hawthorn, or pear types, or individually 04.IX.2015. T. H. Talibov, A. M. Ibrahimov.

S. tamamschjanae Gabr. species differs from S. arrneniaca Hedl. Species with its leaves narrowing in a wedge shape (not round) to the leaf base, shapes and size of its lobes, hairness, veins, orange color (not red) fruits and from S. persica Hedl. Species with its rhomb and elliptic shape leaves that are dark green on the top and green white hairy short sharp lobed leaves, bent fruit stalks and colour of its fruits.

\section{Conclusion}

Thus, on basis of the analysis of herbarium materials collected during the expeditions of 2004-2017 and by literature review, we registered that 19 species of Sorbus L. species are found in the wild flora of the Nakhchivan Autonomous Republic. The species S. aucuparia (VU A2c+3cd) is included in the Red Book of Azerbaijan (Red Book of the Republic of Azerbaijan, 2013). Herbarium samples of S. aucuparia L., S. boissieri Schneid., S. baldascii Deg. et Fritsch. ex Schneid., S. roopiana Bordz., S. luristanica (Bornm.) Schönbeck-Temesy, S. subfusca (Ledeb.) Boiss., S. takhtajanii Gabr., S. persica Hedl., S. graeca (Spach) Lood. ex Schauer, S. turcica Zinserl., S. umbellata (Desf.) Fritsch, S. albovii Zinserl., S. armeniaca Hedl., S. buschiana Zinserl., S. caucasica Zinserl., S. fedorovii Zaikonn., S. kusnetzovii Zinserl., S. migarica Zinserl. and S. tamamschjanae Gabr. collected during the expeditions were delivered for storage in the Herbarium Funds of the Institute of Botany of the Academy of Science of Azerbaijan and Institute of Bioresources of the Nakhchivan branch of the Academy of Science of Azerbaijan.

Despite rowan trees being widely distributed in the forests of the territory of the Nakhchivan Autonomous Republic, we registered that they are mostly present in high, middle, and sometimes lower mountain ranges at the edges of forests, mostly individually or in small groups. We suggested that rowan species are the subdominant tree plants in the arid and sparse forests.

\section{References}

Areas of trees and shrubs of the USSR (1980). Nauka, Leningrad (in Russian). Askerov, A. M. (2016). The Plant World of Azerbaijan (Embryophyta). TEAS Press Publishing House, Baku (in Azerbaijan).

Batsatsashvili, K., Mehdiyeva, N., Fayvush, G., Kikvidze, Z., Khutsishvili, M., Maisaia, I., Sikharulidze, S., Tchelidze, D, Aleksanyan, A., Alizade, V. Zambrana, N. Y. P., Bussmann, R. W. (2017). Sorbus aucuparia L., Sorbus torminalis (L.) Crantz. In: Ethnobotany of the Caucasus, 10, 665-672.

Castellano, G., Marino, P., Maria Raimondo, F., \& Spadaro, V. (2012). Sorbus busambarensis (Rosaceae), a new endemic species of Sicily. Plant Biosystems, 146, 338-344.
Czerepanov, S. K. (1995). Vascular plants of Russia and adjacent states (within the former USSR). Peace and Family-95, St. Petersburg (in Russian).

Gabrielyan, E. T. (1978). Sorbus L. of Western Asia and the Himalayas. Publishing House of Academy of Sciences Arm. SSR, Yerevan (in Russian).

Gachechiladze, K. A. (1965). Dendroflora of the Caucasus (Wild and cultivated trees and shrubs). Metsniereba, Tbilisi (in Russian).

Gasumova, T. A., Aliyeva, Z. S., \& Safguliyeva, T. J. (2014). Critical review of the genus Sorbus (Rosaceae) in Azerbaijan. Proceedings of Azerbaijan National Academy of Sciences, Biological and Medical Sciences, 69(3), 16-21 (in Russian)

Grossheim, A. A. (1952). Genus Sorbus L. Flora of the Caucasus. Publishing House of Academy of Sciences of the USSR, Moscow, Leningrad (in Russian).

Ibragimov, A. M. (2008). The systematic analysis and zones of distribution species of Sorbus L. in flora of Nakhcivan Autonomus Republic. News of Nakhchivan Section of Azerbaijan National Academy of Sciences, The Series of Natural and Technical Sciences, 4, 84-96 (in Azerbaijan).

Konovalov, I. N. (1954). Genus Sorbus L. Trees and Shrubs of the USSR. Publishing House of Academy of Sciences of the USSR, Moscow, Leningrad (in Russian).

Lachashvili, N. J., Eradze, N. V., \& Khetsuriani, L. D. (2017). Conspectus of trees and shrubs of Tbilisi environs (East Georgia, South Caucasus). Annals of Agrarian Science, 15(1), 118-129.

Mammadov, T. S., Iskandar, E. O., \& Talibov, T. H. (2016). Rare trees and shrubs of Azerbaijan. Elm, Baku (in Azerbaijan).

Németh, C. (2015). Taxonomical revision of Sorbus pseudosemi incisa (Rosaceae), a stenoendemic whitebeam from the Vértes Mts (Hungary), with the description of a new species, Sorbus pyricarpa. Studia Botanica Hungarica, 46(2), 157-174.

Özgür Eminagaoglu, O., Ozkaya, M. S., \& Akpulat, H. A. (2012). A new record for the fl ora of Turkey: Sorbus caucasica var. caucasica (Rosaceae), Turkish Journal of Botany, 36, 426.

Prilipko, L. I. (1954). Genus Sorbus L. In: Flora of Azerbaijan. Publishing House of Academy of Sciences of Azerbaijan SSR, Baku (in Russian).

Red Book of the Republic of Azerbaijan. Rare and endangered plant and mushroom species. Second edition (in Azerbaijan).

Rich, T. C. G., Green, D., Houston, L., Lepsı, M., Ludwig, S., \& Pellicer, J. (2015). British Sorbus (Rosaceae): Six new species, two hybrids and a new subgenus. New Journal of Botany, 4(1), 2-12.

Somlyay, L., Zsuzsa Lisztes-Szabó, Z., \& Sennikov, A. N. (2016). Atlas florae Europaeae. Notes 29. Two new species of Sorbus (Rosaceae) endemic to Hungary, previously confused with S. subdanubialis. Annales Botanici Fennici, 53, 361-372.

Talibov, T. H., \& İbragimov, A. M. (2013). The dendroflora of Nakhchivan Autonomous Republic. News of Nakhchivan Section of Azerbaijan National Academy of Sciences. The Series of Natural and Technical Sciences, 4, 6077 (in Azerbaijan).

Talibov, T. H., Ibrahimov, A. M. (2015). Economically valuable woody plants of the Nakhchivan Autonomous Republic of Azerbaijan. Hortus Botanicus, 10, 78-82 (in Russian).

Trees and shrubs of Azerbaijan (1970). Science, Baku (in Azerbaijan).

Zaikonnikova, T. I. (1973). Sorbus migarica Zinserl. in Caucaso. Novitates Systematicae Plantarum Vascularium, 10, 167-172 (in Russian).

Zaikonnikova, T. I. (1974). New species of Sorbus L. in the Caucasus. Botanical Journal, 59(11), 1605-1608 (in Russian).

Zaikonnikova, T. I. (1975). Notae criticae de generis Sorbus L. Speciebus nonnullis e Caucaso. Novitates Systematicae Plantarum Vascularium, 12, 116-121 (in Russian).

Zaikonnikova, T. I. (1980). Ad quaestionem de amitu specie Caucasicae Sorbus subfusca (Ledeb.) Boiss. Novitates Systematicae Plantarum Vascularium, 17, 145-152 (in Russian).

Zinzerling, Y. D. (1939). Genus Sorbus L. In: Flora of the USSR. Publishing House of Academy of Sciences of the USSR, Moscow, Leningrad (in Russian). 